\title{
Determinants of Employee Innovative Behavior in Thai Real Estate Companies
}

\author{
Submitted 12/12/20, $1^{\text {st }}$ revision 28/01/21, $2^{\text {nd }}$ revision 19/02/21, accepted 20/03/21
}

Thanatchaporn Jaruwanakul ${ }^{1}$, Rawin Vongurai ${ }^{2}$

\begin{abstract}
:
Purpose: This research aims to investigate the determinants of employee innovative behavior in Thai real estate companies. The conceptual framework is presented on how symbolic incentive meaning, psychological empowerment, work engagement, transformational leadership, management support, and coworker support affect innovative behavior.

Design/Methodology/Approach: The sample $(n=437)$ was collected from online and offline questionnaires using multi-stage sampling, including purposive sampling, stratified random sampling, and convenience sampling. The study applied the Structural Equation Model (SEM) and Confirmatory Factor Analysis (CFA) to analyze the data to confirm the model's goodness-of-fit and hypothesis.

Findings: The results indicated that symbolic incentive meaning, psychological empowerment, work engagement, transformational leadership, management support, and coworker support have a significant impact on innovative behavior. The researcher also found that symbolic incentive meaning significantly impacted psychological empowerment and work engagement as a mediator of innovative behavior.

Practical Implications: Coworkers' support determines employee innovative behavior, transformational leadership, work engagement, management support, psychological empowerment, and symbolic incentive meaning. Hence, management and human resource managers are recommended to elevate these instruments to enhance innovative behavior at work.

Originality/Value: This study identifies the value and degree of determinants of employee innovative behavior in real estate companies in Thailand.
\end{abstract}

Keywords: Symbolic incentive meaning, psychological empowerment, work engagement, transformational leadership, innovative behavior.

JEL Codes: H2, H21, J54, Q13.

Article Type: Research study.

${ }^{1}$ Ph.D. Candidate, Innovative Technology Management, Graduate School of Business, Assumption University, Bangkok, Thailand, tjaruwanakul@gmail.com

${ }^{2}$ Program Director, Innovative Technology Management, Graduate School of Business, Assumption University, Bangkok, Thailand, rawinvng@au.edu 


\section{Introduction}

Most organizations seek ways to foster different innovation types, including product innovation, service innovation, or process innovation, to improve processes, create differentiation, and enhance efficiency. The innovation can help companies to stay competitive and survive in the modern economic climate. Many research papers have discussed innovative behavior among employees, which drives innovation (Chatchawan et al., 2017).

According to Nusair et al. (2012), the rapid technological changes and market uncertainties have forced organizations to be more responsive and flexible to encourage a new leadership style that can foster innovation. Transformational leadership has received significant attention and is examined as the most prominent influence on innovative behavior that can generate organizations' innovation (Fritz and Ibrahim, 2010).

Bowen and Lawler (1992) specified that psychological empowerment provokes new ideas and fast responses to customers' problems and needs. Hence, employees' psychological empowerment, which comprises meaningfulness, competence, selfdetermination, and impact, can enhance innovative behavior (Sinha et al., 2016). Also, innovative behavior requires a high level of work engagement to generate and implement novel ideas. The components of work engagement, vigor, dedication and absorption, exert innovative behavior enhancement (Tsai, 2018).

The dynamic work environment encourages employees to be more innovative and sustains organizational performance (Shalley et al., 2004). The work environment where employees feel supported and encouraged can increase their intrinsic motivation to achieve effective, innovative behavior. The management (Parker et al., 2006) and coworkers' support (Shalley et al., 2004) were presented as factors that influence innovative behavior in this research. Per the report of Pupatwibul et al. (2019), the real estate sector accounts for $6 \%$ of Thailand's gross domestic product (GDP). Real estate developers in Thailand endorse innovation and push to minimize the impact of technology disruption. Top developers invest aggressively to modify the office spaces to be coworking style, integrate technology into products and services, invest in tech startups, and adopt business models to serve customers better and gain an advantage in the highly competitive market. Therefore, this research aims to identify determinants of employees' innovative behavior in Thailand's real estate companies.

\section{Literature Review}

\subsection{Innovative Behavior}

Innovative behavior is defined as an individual's capability to generate original and potentially useful ideas, including applying those novel ideas into practices. Innovative behavior is the action to improve performance by using new ideas, 
methods, and processes (Chung and Li, 2018). It is a multi-stage process when individuals face problems, and they can create ideas, get support, and find solutions to the specific problem with innovation at work (Afsar and Badir, 2016).

Refer to Janssen (2000), innovative work behavior results from a comprehensive behavior set related to idea creation, idea support, and idea implementation. It refers to an employee's intention and effort to produce beneficial and novel outcomes or innovation at work. Grosser et al. (2017) described three types of work behavior that employees demonstrate, including idea generation, idea promotion, and idea realization.

\subsection{Symbolic Incentive Meaning}

The symbolic meaning reflects two financial incentive schemes provided to employees: pay-for-performance policy and pay equity (Tsai, 2016). Social cognition researchers interpreted the symbolic meaning as the active participation of employees driven by the provided financial incentive. Innovative behavior evolves from the favorable interpretation of symbolic incentive meaning, which results in creative and innovative performance (Kosfeld et al., 2017). Psychological empowerment and work engagement influence socio-psychological outcomes, which illustrates the positive relationship between symbolic incentive meaning and employees' innovative behavior (Tsai, 2018). Thus, the following hypotheses are proposed.

H1: Symbolic incentive meaning has significant impact on psychological empowerment.

H2: Symbolic incentive meaning has significant impact on work engagement. H3: Symbolic incentive meaning has significant impact on innovative behavior.

\subsection{Psychological Empowerment}

The concept of psychological empowerment was proposed by Conger and Kanungo (1988) and Thomas and Velthouse (1990). It refers to an individual voice or role in contracting and influencing organizational activities (Conger and Kanungo, 1988). It is also a tool through empowering leadership that influences both attitudinal and behavioral outcomes of individuals and teams. Refer to the study of Sinha et al. (2016) and Spreitzer (1995), psychological empowerment has four dimensions which are meaning (the individual value on a work role), competence (the belief in one's capability and skill to perform work), impact (the degree of an individuals' ability that can influence organizational performance) and self-determination (an autonomy in making decisions).

Spreitzer et al. (1999) identified that higher psychological empowerment perceptions increase inspiration, innovation, and positive influence. It assures that psychological empowerment is a motivational state which fosters innovative work 
behaviors (Parker et al., 2006). Based on the above discussion, this study proposes the following hypothesis.

H4: Psychological empowerment has significant impact on innovative behavior.

\subsection{Work Engagement}

Work engagement is an intrinsic motivation at work that refers to a positive and fulfilling state of mind (Schaufeli et al., 2006). It involves physical, cognitive, and emotional aspects (Kahn, 1990). Refer to Schaufeli and Bakker (2010), work engagement is conceptualized in three aspects - vigor (endeavor to get work done), dedication (enthusiasm, passion, and pride to performing tasks), and absorption (full concentration, total ownership, and deep immersion about work). These aspects correlate with job satisfaction in the level of cognitive and emotion to performing tasks. According to Montani et al. (2020), the study explored optimal activation related to a moderate workload in which work engagement can deliver the energy that stimulates innovative behavior. The previous research found a positive association between work engagement and innovative work behavior (Agarwal et al., 2012). Hence, the following hypothesis is developed.

H5: Work engagement has significant impact on innovative behavior.

\subsection{Transformational Leadership}

The transformational leadership concept began with Downton (1973) and was extended by Burns (1978) and Bass (1985). Bass (1985) expanded the transformational leadership model to include its success measurement. Transformational leadership occurs when leaders engage with followers and raise one another to higher motivation and morality levels (Burns, 1978). According to Bass (1985), transformational leadership is characterized in four 'I's: individualized consideration, intellectual stimulation, inspirational motivation, and idealized influence. Transformational leaders foster innovative behavior by encouraging employees to achieve common goals (Majumdar and Ray, 2011), motivating individuals to learn and socialize more to find support for implementing their ideas (Kahai et al., 2003). The purpose of this research is to identify whether transformational leadership has a significant impact on innovative behavior. Thus, the following hypotheses are proposed.

H6: Transformational leadership has significant impact on innovative behavior.

\subsection{Management Support}

The definition of management support is the employee's perception of the organizational value contributing to its well-being. Employees demonstrate work interest and achievement when getting support from their managers (Oldham and Cummings, 1996). The support from management and the relationship with 
supervisors have been significantly envisioned in motivating innovative behavior (Hunter and Cushenbery 2011). The study of Attiq et al. (2017) recognized that the impact of management support was an important predecessor for innovative and unrestricted behavior (Hoon Song et al., 2012). Accordingly, this research hypothesizes that management support has a significant impact on innovative behavior.

H7: Management Support has significant impact on innovative behavior.

\subsection{Coworkers Support}

Coworkers are defined as the work environment (Schneider, 1987), individuals working and interacting with each other to performing daily tasks in the same organization. The supportive work environment stimulates employees to exchange expertise and knowledge and work openly, actively, and constructively. Employees who work in organizations with strong coordinating, networking, and social supporting, tend to be innovative at the workplace (Prieto and Perez-Santana, 2014). Also, the perception of coworkers' support has reached consideration of innovative work behavior in prior research (Parker et al., 2006; Shalley et al., 2004). Hence, the following hypothesis is derived.

H8: Coworkers support has significant impact on innovative behavior.

\section{Research Methods and Materials}

\subsection{Research Framework}

The conceptual framework is developed from studying related theoretical frameworks. It is adapted from four theoretical models. First, the study of Tsai (2018) verified symbolic incentive meaning (SIM) has a positive relationship with psychological empowerment, work engagement (WE), and innovative behavior (IB) of knowledge workers. Second, Sinha et al. (2016) examined the role of psychological empowerment (PE) in mediating the relationship between organizational culture, innovative behavior, and work-related attitude. The third research explored the curvilinear effect of transformational leadership (TL) on innovative behavior among R\&D teams in South Korea (Chung and Li, 2018). Last, Prieto and Perez-Santana (2014) researched human resource practices that are positively related to innovative work behavior with the mediation of two work environment variables: management support (MS) and coworkers support (CS). The conceptual framework of this study is shown in Figure 1.

This study aims to examine the determinants of innovative behavior (IB) towards various variables, which are symbolic incentive meaning (SIM), psychological empowerment (PE), work engagement (WE), transformational leadership (TL), management support (MS), coworkers support (CS) among employees in real estate developers in Thailand. Furthermore, the research investigates the causal 
relationship between variables to reveal the impact of these factors on innovative behavior.

Figure 1. Conceptual Framework

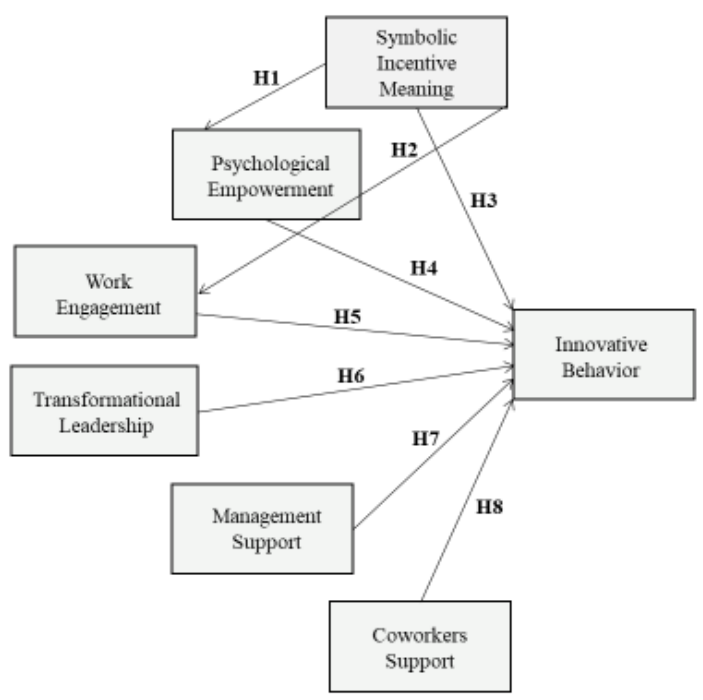

Source: Own creation.

\subsection{Methodology}

The researcher applied probability sampling and nonprobability sampling for the quantitative method in this study. The developed questionnaire was distributed online and offline to the target group of employees in middle to top management who have been working in the top twenty largest public listed real estate companies by market capitalization from the Stock Exchange of Thailand. The collected data has been analyzed for factors that affect employee's innovative behavior. The questionnaire consists of three parts. The first part includes screening questions to identify the respondents. Secondly, a 5-point Likert scale was used to measure seven different variables, ranging from strong disagreement (1) to strong agreement (5) to analyze all hypotheses. Finally, questions on demographic factors have been collected based on respondents' gender, age, and highest education. For pilot testing, the index of item- objective congruence (IOC) has been applied. Then, the questionnaire was given to 50 respondents.

Cronbach's alpha method was used to verify the reliability of the respondents. After the reliability test, the questionnaire was distributed to target respondents, which resulted in 437 accepted responses. The researcher analyzed the data collected through SPSS AMOS 26.0. Afterward, Confirmatory Factor Analysis (CFA) was conducted to test the convergence accuracy, and the validation results were classified. The measurement model fits the overall test with given data to ensure the 
model's accuracy and reliability. Finally, the researcher used the Structural Equation Model (SEM) to examine the effect of variables.

\subsection{Population and Sample Size}

The population used in this research consists of employees in the middle to top-level executives (Sinha et al., 2016) who have been working in the twenty largest public listed real estate companies in Thailand by market capitalization. The sample size for Structural Equation Models suggested by Kline (2011) is at least 200 respondents should participate. For this study, the questionnaire was distributed to 500 respondents. After screening all the responses, 437 responses were considered eligible for further use in this study.

\subsection{Sampling Technique}

The researcher used multi-stage sampling in the sampling procedure for this study. The first stage is a nonprobability sampling, using purposive sampling to select the top twenty public listed real estate companies by market capitalization. The second stage adapted the probability sampling method of stratified random sampling of a total employee of these twenty companies, which are 27,825 and was distributed by a ratio as shown in Table 1. In the third stage, the researcher employed nonprobability sampling by using convenience sampling. Then, the purposive sampling was carried out to select employees from the middle to top management level.

Table 1. Population and Sample Size by Company

\begin{tabular}{|l|c|c|c|}
\hline $\begin{array}{c}\text { Company } \\
\text { Public Company } \\
\text { Limited) }\end{array}$ & $\begin{array}{c}\text { Market } \\
\text { Capitalization (In } \\
\text { Million Thai Bath) }\end{array}$ & $\begin{array}{c}\text { Approximate } \\
\text { Population Size }\end{array}$ & $\begin{array}{c}\text { Sample } \\
\text { Size }\end{array}$ \\
\hline Land and Houses & 130,252 & 804 & 13 \\
\hline Supalai & 44,147 & 1,262 & 20 \\
\hline Preuksa Real Estate & 43,770 & 2,908 & 46 \\
\hline Quality Houses & 31,175 & 1,083 & 17 \\
\hline AP (Thailand) & 23,437 & 2,571 & 40 \\
\hline Singha Estate & 23,029 & 3,875 & 60 \\
\hline Sansiri & 20,659 & 1,870 & 29 \\
\hline Origin Property & 19,838 & 949 & 15 \\
\hline $\begin{array}{l}\text { Golden Land Property } \\
\text { Development }\end{array}$ & 19,055 & 480 & 8 \\
\hline Grand Canal Land & 17,420 & 2,200 & 35 \\
\hline Univentures & 11,663 & 674 & 11 \\
\hline SC Asset Corporation & 11,285 & 877 & 14 \\
\hline Ananda Development & 10,732 & 720 & 11 \\
\hline Noble Development & 9,860 & 355 & 6 \\
\hline L.P.N. Development & 9,666 & 3,915 & 61 \\
\hline Property Perfect & 6,674 & 1,155 & 18 \\
\hline Areeya Property & 6,125 & 514 & 8 \\
\hline
\end{tabular}




\begin{tabular}{|l|c|c|c|}
\hline Lalin Property & 4,903 & 649 & 10 \\
\hline Sena Development & 4,812 & 750 & 12 \\
\hline Raimon Land & 4,465 & 214 & 3 \\
\hline Total & & $\mathbf{2 7 , 8 2 5}$ & $\mathbf{4 3 7}$ \\
\hline
\end{tabular}

Source: Stock Exchange of Thailand (2020).

The questionnaires were distributed online and offline. The data collection had taken from February to October 2020. The data were screened to ensure that respondents met the target group of employees working in the twenty largest real estate company by market capitalization, titled in the middle to top management level. The online distribution was made via social networks, including Email, Line Chat applications, Facebook, and LinkedIn. The respondents were encouraged to share the questionnaire's link with their peers, who also met the required criteria. The offline or paper-based survey was given directly to employees and distributed through HR managers.

\section{Results and Discussion}

\subsection{Demographic Factors}

The demographic profile of the target audience of 437 respondents is summarized in Table 2. Most of the respondents were male, representing $51.9 \%$, whereas female respondents represented $48.1 \%$. In terms of age, the largest segment in this study $(61.3 \%)$ was $31-40$ years old respondents; $23.3 \%$ were $41-50$ years old: $11.7 \%$ were less than 30 years old; $3.7 \%$ were over 50 years old. For the respondents' education, the majority was Bachelor's degree, representing 93.6\% whereas Master's degree represented 3.7\%, followed by below Bachelor's degree $(2.3 \%)$ and Doctorate's degree $(0.5 \%)$.

Table 2. Demographic Profile

\begin{tabular}{|l|l|c|c|}
\hline \multicolumn{2}{|c|}{ Demographic and Behavior Data (N=437) } & Frequency & Percentage \\
\hline Gender & Male & 227 & $51.9 \%$ \\
& Female & 210 & $48.1 \%$ \\
\hline Age & Less than 30 years old & 51 & $11.7 \%$ \\
& $31-40$ years old & 268 & $61.3 \%$ \\
& 41-50 years old & 102 & $23.3 \%$ \\
& More than 50 years old & 16 & $3.7 \%$ \\
\hline Education & Below Bachelor's degree & 10 & $2.3 \%$ \\
& Bachelor's degree & 409 & $93.6 \%$ \\
& Master's degree & 16 & $3.7 \%$ \\
& Doctorate's degree & 2 & $0.5 \%$ \\
\hline
\end{tabular}

Source: Own creation.

\subsection{Confirmatory Factor Analysis (CFA)}

Confirmatory Factor Analysis (CFA) was utilized in this study. The CFA result showed that all items in each variable are significant and present factor loading to 
prove discriminant validity. The significance of factor loading of each item and acceptable values define the goodness of fit (Hair et al., 2006). Factor loadings are higher than 0.30 and p-value of lower than 0.05. According to Fornell and Larcker (1981), the construct reliability is higher than the cut-off point of 0.7 and the average variance extracted was greater than the cut-off point of 0.5 in Table 3 . All the estimates are significant.

Table 3. Confirmatory Factor Analysis Result, Composite Reliability (CR) and Average Variance Extracted (AVE)

\begin{tabular}{|c|c|c|c|c|c|c|}
\hline Variables & $\begin{array}{c}\text { Source of } \\
\text { Questionnaire } \\
\text { (Measurement } \\
\text { Indicator) }\end{array}$ & $\begin{array}{c}\text { No. } \\
\text { of } \\
\text { Item }\end{array}$ & $\begin{array}{c}\text { Cronbach's } \\
\text { Alpha }\end{array}$ & Factors Loading & CR & AVE \\
\hline $\begin{array}{l}\text { Symbolic } \\
\text { Incentive } \\
\text { Meaning (SIM) }\end{array}$ & Tsai (2018) & 9 & 0.910 & $0.902-0.604$ & 0.923 & 0.575 \\
\hline $\begin{array}{l}\text { Psychological } \\
\text { Empowerment } \\
\text { (PE) }\end{array}$ & $\begin{array}{l}\text { Sinha } \text { et. al. } \\
\text { (2016) and } \\
\text { Spreitzer (1995) } \\
\end{array}$ & 12 & 0.949 & $0.781-0.565$ & 0.971 & 0.480 \\
\hline $\begin{array}{l}\text { Work } \\
\text { Engagement } \\
(\mathrm{WE})\end{array}$ & Tsai (2018) & 6 & 0.912 & $0.919-0.699$ & 0.920 & 0.660 \\
\hline $\begin{array}{l}\text { Transformational } \\
\text { Leadership (TL) }\end{array}$ & \begin{tabular}{|l}
$\begin{array}{l}\text { Chung and } \mathrm{Li}, \\
(2018)\end{array}$ \\
\end{tabular} & 7 & 0.654 & $0.948-0.496$ & 0.690 & 0.938 \\
\hline $\begin{array}{l}\text { Management } \\
\text { Support (MS) }\end{array}$ & $\begin{array}{l}\text { Prieto and } \\
\text { Perez-Santana } \\
(2014)\end{array}$ & 5 & 0.733 & $0.959-0.784$ & 0.760 & 0.940 \\
\hline $\begin{array}{l}\text { Coworkers } \\
\text { Support (CS) }\end{array}$ & $\begin{array}{l}\text { Prieto and } \\
\text { Perez-Santana } \\
(2014) \\
\end{array}$ & 6 & 0.918 & $0.888-0.679$ & 0.926 & 0.678 \\
\hline $\begin{array}{l}\text { Innovative } \\
\text { Behavior (IB) }\end{array}$ & $\begin{array}{l}\text { Prieto and } \\
\text { Perez-Santana } \\
(2014)\end{array}$ & 5 & 0.921 & $0.940-0.765$ & 0.926 & 0.716 \\
\hline
\end{tabular}

Source: Own creation.

The square root of average variance extracted in Table 4 indicated that all the correlations are greater than those of that variable. GFI, AGFI, NFI, IFI, CFI, RMR, and RMSEA are used as indicators for a good model fit in CFA testing. The convergent validity and discriminant validity are verified as the value of this study shown in Table 5 is greater than acceptable values. Therefore, convergent validity and discriminant validity are assured. Moreover, these model measurement results formed discriminant validity and validation to perform the validity of subsequent structural model estimation.

Table 4. Discriminant Validity

\begin{tabular}{|l|l|l|l|l|l|l|l|}
\hline & \multicolumn{7}{|c|}{ Factor Correlations } \\
\hline Variables & SIM & PE & WE & TL & MS & CS & IB \\
\hline SIM & $\mathbf{0 . 7 5 8}$ & & & & & & \\
\hline
\end{tabular}




\begin{tabular}{|l|l|l|l|l|l|l|l|}
\hline PE & 0.517 & $\mathbf{0 . 6 9 3}$ & & & & & \\
\hline WE & 0.391 & 0.621 & $\mathbf{0 . 8 1 2}$ & & & & \\
\hline TL & 0.414 & 0.569 & 0.551 & $\mathbf{0 . 9 6 9}$ & & & \\
\hline MS & 0.426 & 0.638 & 0.612 & 0.811 & $\mathbf{0 . 9 7 0}$ & & \\
\hline CS & 0.491 & 0.618 & 0.619 & 0.480 & 0.600 & $\mathbf{0 . 8 2 3}$ & \\
\hline IB & 0.447 & 0.663 & 0.598 & 0.436 & 0.462 & 0.665 & $\mathbf{0 . 8 4 6}$ \\
\hline
\end{tabular}

Note: The diagonally listed value is the AVE square roots of the variables.

Source: Own creation.

Table 5. Goodness of Fit

\begin{tabular}{|l|l|l|}
\hline \multicolumn{1}{c|}{ Index } & \multicolumn{1}{c|}{ Acceptable Values } & \multicolumn{1}{c|}{ Values } \\
\hline CMIN/DF & $<3.00$ (Hair et al., 2006$)$ & 2.937 \\
\hline GFI & $\geq 0.90$ (Hair et al., 2006) & 0.964 \\
\hline AGFI & $\geq 0.80$ (Segars and Grover, 1993) & 0.948 \\
\hline NFI & $\geq 0.90$ (Bentler and Bonnet, 1980) & 0.923 \\
\hline IFI & $0-1$ (Arbuckle, $2008 ;$ Ho, 2006) & 0.935 \\
\hline CFI & $\geq 0.90$ (Hair et al., 2006) & 0.934 \\
\hline RMR & $<0.05$ (Hair et al., 2006) & 0.043 \\
\hline RMSEA & $\leq 0.08$ ((Hair et al., 1998) & 0.044 \\
\hline
\end{tabular}

Note: $C M I N / D F=$ The ratio of the chi-square value to degree of freedom, GFI $=$ goodnessof-fit index, AGFI = adjusted goodness-of-fit index, NFI = normalized fit index, IFI = Incremental Fit Indices, CFI = comparative fit index, $R M R=$ root mean square residual, and RMSEA = root mean square error of approximation.

Source: Own creation.

\subsection{Structural Equation Model (SEM)}

Structural Equation Modeling (SEM) verified the relationship between constructs in a model and covers measurement falsity in the structure coefficient (Hair et al., 2010). The goodness of fit index is estimated (see Table 5) for demonstration. The measurement for model fit should not be over 3 for Chi-square/degrees-of-freedom (CMIN/DF) ratio, and GFI and CFI should be higher than 0.9 as recommended by Hair et al. (2006). Subsequent of the process in SEMs and adjusting the model by using SPSS AMOS version 26, the results of fit index were presented good fit which are $\mathrm{CMIN} / \mathrm{DF}=2.937, \mathrm{GFI}=0.964, \mathrm{AGFI}=0.948, \mathrm{NFI}=0.923, \mathrm{IFI}=0.935, \mathrm{CFI}=$ $0.934, \mathrm{RMR}=0.043$ and $\mathrm{RMSEA}=0.044$, according to the measurable criteria that mentioned in Table 4.

\subsection{Research Hypothesis Testing Result}

The significance of each variable in the research model is assessed from its regression weights and R2 variances. The result from Table 6 postulated that all hypotheses were supported with a significance at $\mathrm{p}=0.05$. Coworkers support has the strongest impact toward innovative behavior which demonstrated 0.381 , followed by transformational leadership $(\beta=0.338)$, work engagement $(\beta=0.290)$, management support $(\beta=0.280)$, psychological empowerment $(\beta=0.208)$, and symbolic incentive meaning $(\beta=0.108)$. 
Table 6. Hypothesis Result of the Structural Model

\begin{tabular}{|l|l|l|l|l|l|}
\hline Hypotheses & \multicolumn{1}{|c|}{ Paths } & $\begin{array}{c}\text { Standardized } \\
\text { Path } \\
\text { Coefficients } \\
(\boldsymbol{\beta})\end{array}$ & S.E. & $\begin{array}{c}\text { T- } \\
\text { Value }\end{array}$ & $\begin{array}{c}\text { Tests } \\
\text { Result }\end{array}$ \\
\hline H1 & SIM $\rightarrow$ PE & 0.581 & 0.064 & $8.829^{*}$ & Supported \\
\hline H2 & SIM $\rightarrow$ WE & 0.448 & 0.072 & $7.533^{*}$ & Supported \\
\hline H3 & SIM $\rightarrow$ IB & 0.108 & 0.066 & $2.070^{*}$ & Supported \\
\hline H4 & PE $\rightarrow$ IB & 0.208 & 0.063 & $4.315^{*}$ & Supported \\
\hline H5 & WE $\rightarrow$ IB & 0.290 & 0.046 & $6.583^{*}$ & Supported \\
\hline H6 & TL $\rightarrow$ IB & 0.338 & 0.079 & $7.152^{*}$ & Supported \\
\hline H7 & MS $\rightarrow$ IB & 0.280 & 0.026 & $7.529^{*}$ & Supported \\
\hline H8 & CS $\rightarrow$ IB & 0.381 & 0.039 & $9.464^{*}$ & Supported \\
\hline
\end{tabular}

Note: $* p<0.05$.

Source: Own creation.

\section{Conclusions and Recommendation}

\subsection{Conclusion}

In this study, the researchers investigate the determinants of employees' innovative behavior in real estate developers in Thailand. The hypotheses were developed as the conceptual framework to examine how symbolic incentive meaning, psychological empowerment, work engagement, transformational leadership, management support, and coworker support impact innovative behavior. The questionnaires were distributed to the target group of employees in the middle to top management who work in the top twenty largest public listed real estate companies by market capitalization from the Stock Exchange of Thailand. The data has been analyzed for factors that affect employee innovative behavior. Confirmatory Factor Analysis (CFA) was used to analyze the collected data for validity. The research model's validity and reliability persuasive factors influencing employees' innovative behavior were analyzed by using Structural Equation Model (SEM).

The research explained the following findings. First, coworker support has the strongest significant influence on innovative behavior among employees. Prieto and Perez-Santana (2014) investigated the relationship between coworkers' support and innovative work behaviors. The high level of engagement, long-term commitment, the meaningfulness of accomplishment, and social support among coworkers are significant ways to endorse employee innovative behavior and organizational values (Afsar and Badir, 2016). Second, transformational leadership has a significant impact on employee innovative behavior at work. Transformational leaders have a vision that can motivate their employees, raise their willingness to perform beyond expectations, and challenge them to adopt innovative methods in their work. Third, work engagement showed a significant impact on the innovative behavior of employees. Work engagement is the construction of absolute energy, strong resilience, and diligence to get work done (vigor), the sense of enthusiasm, passion and pride about the work (dedication) and full attention, total obsession, and deep 
immersion in work activities (absorption) (Griffin et al., 2008; Sahoo and Sahu, 2009). Tsai (2018), also found a positive relationship between innovativeness and the three dimensions of work engagement.

Next, the result of this study showed management support has a significant impact on innovative behavior. Prieto and Perez-Santana (2014) explored that management support correlated with innovative work behavior. Management support and relationships with supervisors have been often projected as crucial in stimulating innovative behaviors (Parker et al., 2006; Hunter and Cushenbery, 2011; Shalley et al., 2004). Therefore, employees who receive support from their management would feel more secure and involve in innovative work behavior (Prieto and PerezSantana, 2014). Fifth, this study presented the significant impact of psychological empowerment on innovative behavior. Psychological empowerment is a motivational state which fosters innovative work behaviors (Afsar and Badir, 2016; Parker et al., 2006). Lastly, this study exhibited the influence of symbolic incentive meaning on innovative behavior. The research of Tsai (2018) indicated that symbolic incentive meaning could enhance innovative behavior.

Moreover, psychological empowerment and work engagement were proven as a partial mediator of significant incentive meaning and positively impacted innovative behavior. The organizational factors, which reside with job design, leadership styles, and financial incentive, were discovered to play as the partial mediation of psychological empowerment (Sinha et al., 2016) and work engagement (Owens et al., 2016) innovative behavior. In conclusion, according to the research results' explanations and justifications from the above, it clearly demonstrated that the research results had met the objective on the persuasive factors affecting innovative behavior among top-middle management employees in the selected real estate companies in Thailand.

\subsection{Recommendation}

This study's findings revealed that determinants of employee innovative behavior in real estate developers in Thailand are symbolic incentive meaning, psychological empowerment, work engagement, transformational leadership, management support, and coworkers support. Therefore, the researcher recommended developing these features in the organization to create innovative behavior among employees in the company. In theoretical and practical implications, management actions should create initiatives to promote empowering leadership and innovative behavior.

Employees are encouraged to express and exchange ideas in various communication channels. The recommendations are to design the process of work and align the system (Tsai, 2018). Furthermore, team leaders should use a proper level of transformational leadership to enhance the members' innovative behavior. It requires charismatic leadership and effective communication (Chung and Li, 2018). Consequently, leaders need to provide flexible training programs to elevate employees' skills and capabilities. Human resources managers also need to select 
and empower individuals' work-related capability and development and ensure that high-quality relationships of these individuals with supervisors and coworkers set a foundation of innovative work behavior. It involves the enhancement of ability and opportunity to cultivate a supportive work environment including management and coworkers support which would stimulate employees' initiatives and subsequent company's innovation performance (Prieto and Perez-Santana, 2014). In conclusion, this study's outcome is useful for management and human resources development to scale and optimize employee performance to achieve organizational success.

\subsection{Limitation and Further Study}

This study has limitations that should be investigated more for future researches. This research only focuses on employees in the middle to the top management level in the twenty largest public listed real estate companies by the market capitalization value from the Stock Exchange of Thailand. The different schemes probably present different outcomes, e.g., a different industry, the organization's size, organizational culture, etc. Future studies may explore samples more in another geographical region and other industries to investigate similar or different findings. The extended study can include the variables to investigate the innovative behavior such as work environment, job autonomy, team learning, etc.

Furthermore, examining the relationship between an organizational culture that links to innovation may create more opportunities to develop a highly efficient value to influence innovative behavior. Future research can also study the organizational performance in financial and non-financial outcomes affecting employees' innovative behavior to investigate the clear benefit of such behavior could create a greater value and achieve a greater return for companies.

\section{References:}

Afsar, B., Badir, Y. 2016. The mediating role of psychological empowerment on the relationship between person-organization fit and innovative work behavior. Journal of Chinese Human Resource Management, 7(1), 5-26.

Agarwal, U.A., Datta, S., Blake-Beard, S., Bhargava, S. 2012. Linking LMX, innovative work behavior and turnover intentions. Career Development International, 17(3), 208-230.

Attiq, S., Wahid, S., Javaid, N., Kanwal, M., Shah, H. 2017. The Impact of Employees' Core Self-Evaluation Personality Trait, Management Support, Co-worker Support on Job Satisfaction, and Innovative Work Behavior. Pakistan Journal of Psychological Research, 32(1), 247-271.

Bass, B.M. 1985. Leadership and Performance Beyond Expectations. New York, Free Press.

Bowen, D.E., Lawler, E.E. 1992. The empowerment of service workers: what, why, how, and when. Sloan Management Review, 33(3), 31-39.

Burns, J.M. 1978. Leadership. New York, Harper and Row.

Chatchawan, R., Trichandhara, K., Rinthaisong, I. 2017. Factors Affecting Innovative Work Behavior of Employees in Local Administrative Organizations in the South of 
Thailand. International Journal Social Sciences and Management, 4(3), 154-157. https://doi.org/10.3126/ijssm.v4i3.17755.

Chung D.S., Li, J.M. 2018. Curvilinear effect of transformational leadership on innovative behavior among R\&D teams in South Korea Moderating role of team learning. Journal of Organizational Change Management. https://doi.org/10.1108/JOCM01-2017-0017.

Conger, J.A., Kanungo, R.N. 1988. The empowerment process: integrating theory and practice. Academy of Management Review, 13(3), 471-482.

Downton, J.V. 1973. Rebel leadership: Commitment and charisma in the revolutionary process. New York, Free Press.

Fornell, C.G., Larcker, D.F. 1981. Evaluating structural equation models with unobservable variables and measurement error. Journal of Marketing Research, 18(1), 39-50.

Fritz, D., Ibrahim, N. 2010. The impact of leadership longevity on innovation in a religious organization. Journal of Business Ethics, 96, 223-231.

Griffin, M.A., Parker, S.K., Neal, A. 2008. Is behavioral engagement a distinct and useful construct? Industrial and Organizational Psychology, 1(1), 48-51.

Grosser, T.J., Venkataramani, V., Labianca, G.J. 2017. An alter-centric perspective on employee innovation: the importance of alters' creative self-efficacy and network structure. Journal of Applied Psychology, 102(9), 1360-1374.

Hair, J., Black, W., Babin, B., Anderson, R. 2010. Multivariate Data Analysis: A Global Perspective, $7^{\text {th }}$ edition. Pearson Education, Harlow, UK.

Hair, J., Black, W., Babin, B., Anderson, R., Tatham, R. 2006. Multivariate Data Analysis, $6^{\text {th }}$ edition. Pearson Education, Harlow, UK.

Hoon Song, J., Kolb, J.A., Hee, U., Kyoung, K.H. 2012. Role of transformational leadership in effective organizational knowledge creation practices: Mediating effects of employees’ work engagement. Human Resource Development Quarterly, 23(1), 65-101.

Hunter, S.T., Cushenbery, L. 2011. Leading for innovation: direct and indirect influences. Advances in Developing Human Resources, 3(3), 248-265.

Janssen, O. 2000. Job demands, perceptions of effort - reward fairness and innovative work behavior. Journal of Occupational and Organizational Psychology, 73(3), 287302.

Kahai, S.S., Sosik, J.J., Avolio, B.J. 2003. Effects of leadership style, anonymity, and rewards on creativity-relevant processes and outcomes in an electronic meeting system context. The Leadership Quarterly, 14(4), 499-524.

Kahn, W.A. 1990. Psychological conditions of personal engagement and disengagement at work. Academy of Management Journal, 33(4), 692-724.

Kline, R.B. 2011. Principles and practice of structural equation modeling, $3^{\text {rd }}$ edition. Guilford Press, New York, NY.

Kosfeld, M., Neckermann, S., Yang, X. 2017. The effects of financial and recognition incentives across work contexts: the role of meaning. Economic Inquiry, 55(1), 237-247.

Majumdar, B., Ray, A. 2011. Transformational Leadership and Innovative Work Behaviour. Journal of the Indian Academy of Applied Psychology, 37(1), 140-148.

Montani, F., Vandenberghe, C., Khedhaouria, A., Courcy, F. 2020. Examining the inverted U-shaped relationship between workload and innovative work behavior: The role of work engagement and mindfulness. Human Relations, 73(1), 59-93. https://doi.org/10.1177/0018726718819055.

Nusair, N., Ababneh, R., Bae Y.K. 2012. The impact of transformational leadership style on innovation as perceived by public employees in Jordan. International Journal of 
Commerce and Management, 22(3), 182-201.

https://doi.org/10.1108/10569211211260283.

Oldham, G.R., Cummings, A. 1996. Employee creativity: personal and contextual factors at work. Academy of Management Journal, 39(3), 607-634.

Owens, B.P., Baker, W.E., Sumpter, D.M., Cameron, K.S. 2016. Relational energy at work: implications for job engagement and job performance. Journal of Applied Psychology, 101(1), 35-49.

Parker, S.K., Williams, H.M., Turner, N. 2006. Modeling the antecedents of proactive behavior at work. Journal of Applied Psychology, 91(3), 636-652.

Prieto, I.M., Perez-Santana, M.P. 2014. Managing innovative work behavior: the role of human resource practices. Personnel Review, 43(2), 184-208.

Pupatwibul, P., Patamatamkul, P., Danchaivijit, P., Collet, F. 2019. Thailand Hotel Market Research. Jones Lang LaSalle. Retrieved form: http://market.sec.or.th/public/ipos/IPOSGetFile.aspx?TransID=250826\&TransFil $\underline{\mathrm{eSeq}=58 .}$.

Sahoo, C.K., Sahu, G. 2009. Effective employee engagement: the mantra of achieving organizational excellence. Management and Labour Studies, 34(1), 73-84.

Schneider, W.B. 1987. The people make the place. Personnel Psychology, 40(3), 437-453.

Schaufeli, W.B., Bakker, A.B. 2010. Defining and measuring work engagement: bringing clarity to the concept. In: Bakker A.B. and Leiter M.P. (Eds.). Work Engagement: A Handbook of Essential Theory and Research, Psychology Press, New York, NY, 25-38.

Schaufeli, W.B., Bakker, A.B., Salanova, M. 2006. The measurement of work engagement with a short questionnaire: a cross-national study. Educational and Psychological Measurement, 66(4), 701-16.

Shalley, C.E., Zhou, J., Oldham, G.R. 2004. The effects of personal and contextual characteristics on creativity: where should we go from here? Journal of Management, 30(6), 933-958.

Sinha, S., Priyadarshi, P., Kumar, P. 2016. Organizational culture, innovative behavior and work related attitude Role of psychological empowerment. Journal of Workplace Learning, 28(8), 519-535. https://doi.org/10.1108/JWL-06-2016-0055.

Spreitzer, G.M. 1995. Psychological empowerment in the workplace: Dimensions, measurement, and validation. Academy of Management Journal, 38(5), 14421465.

Spreitzer, G.M., De Janasz, S.C., Quinn, R.E. 1999. Empowered to lead: the role of psychological empowerment in leadership. Journal of Organizational Behavior, 20(4), 511-526.

Stock Exchange of Thailand. 2020. Retrieved from: https://www.set.or.th/set/mainpage.do?language=en\&country=US

Thomas, K.W., Velthouse, B.A. 1990. Cognitive elements of empowerment: an "interpretive" model of intrinsic task motivation. Academy of Management Review, 15(4), 666-681.

Tsai, S. 2016. Managing R\&D employee creative performance with symbolic meanings of money. Business Creativity and the Creative Economy, 2(1), 74-87.

Tsai, S. 2018. Innovative behavior of knowledge workers and social exchange attributes of financial incentive: implications for knowledge management. Journal of Knowledge Management, 22(8), 1712-1735. https://doi.org/10.1108/JKM-072017-0293. 